\title{
Energy partitioning and methane emission by sheep fed sorghum silages at different maturation stages
}

\author{
[Partição de energia e emissão de metano por ovinos alimentados com silagem de sorgo \\ em diferentes estádios de maturação] \\ F.S. Machado ${ }^{1}$, N.M. Rodríguez ${ }^{2}$, L.C. Gonçalves ${ }^{2}$, J.A.S. Rodrigues ${ }^{3}$, M.N. Ribas ${ }^{2}$, \\ F.P. Pôssas ${ }^{2}$, D.G. Jayme ${ }^{2}$, L.G.R. Pereira ${ }^{1}$, A.V. Chaves ${ }^{4}$, T.R. Tomich ${ }^{1}$ \\ ${ }^{1}$ Embrapa Gado de Leite - Juiz de Fora, MG \\ ${ }^{2}$ Universidade Federal de Minas Gerais - Escola de Veterinária - Belo Horizonte, MG \\ ${ }^{3}$ Embrapa Milho e Sorgo - Sete Lagoas, MG \\ ${ }^{4}$ Faculty of Veterinary Science - The University of Sydney - Sydney - NSW, Australia
}

\begin{abstract}
Energy partitioning and methane production by sheep fed silages of three commercially available sorghum hybrids (BRS 610, BR 700 and BRS 655) harvested at three maturation stages (milk, soft dough and floury) were evaluated in open circuit respiration chambers. A complete randomized design was used in a $3 \times 3$ (hybrids $\times$ maturity stages) factorial arrangement, and the means were compared by the Student-Newman-Keuls $(\mathrm{SNK})$ test $(\mathrm{P}<0.05)$. The intake of dry matter, digestible dry matter, gross energy, digestible energy and metabolizable energy were not affected by maturation stage, but were influenced by hybrid. The net energy intake was influenced by maturity and sorghum genetics. The fecal output represented the main source of energy loss, as percentage of gross energy intake (48\% to 52\%), followed by heat increment (10\% to $19 \%)$, methane emissions ( $4 \%$ to $6 \%$ ) and urine (1\% to $2 \%)$. There were no differences $(\mathrm{P}>0.10)$ among the treatments for the apparent digestibility of gross energy and metabolizability $\left(\mathrm{q}_{\mathrm{m}}\right)$. An interaction $(\mathrm{P}<0.05)$ between sorghum hybrid and maturation stages was observed for the efficiency of metabolizable energy utilization for maintenance $(\mathrm{km})$, which ranged between 0.53 and 0.78 . No differences $(\mathrm{P}>0.10)$ among treatments occurred in the daily methane production. There is substantial genetic diversity within sorghum species, determining different nutritional values. Sorghum genetics and maturity at harvest should not be an opportunity to reduce the contribution of agriculture to methane emissions.
\end{abstract}

Keywords: greenhouses gas, nutritional value, net energy, respirometry

\section{RESUMO}

A partição de energia e a produção de metano por ovinos alimentados com silagens de três híbridos de sorgo comerciais (BRS 610, BR 700 e BRS 655), colhidos em três estádios de maturação (leitoso, pastoso e farináceo), foram avaliadas em câmaras respirométricas de circuito aberto. Utilizou-se delineamento inteiramente ao acaso, em arranjo fatorial 3 x 3 (híbridos x estádios de maturação), e as médias foram comparadas pelo teste Student-Newman-Keuls $(S N K)(P<0,05)$. Os consumos de matéria seca, de matéria seca digestível, de energia bruta, de energia digestível e de energia metabolizável não foram afetados pelo estádio de maturação, mas foram influenciados pelo híbrido de sorgo. O consumo de energia líquida foi influenciado pela maturidade e pelo híbrido. As perdas de energia nas fezes representaram a principal fonte de perda energética como porcentagem do consumo de energia bruta (48\% a 52\%), seguida pelo incremento calórico (10\% a 19\%), pela emissão de metano (4\% a 6\%) e pela urina (1 a 2\%). Não houve diferenças $(p>0,10)$ entre os tratamentos para a digestibilidade aparente da

Recebido em 30 de agosto de 2013

Aceito em 20 de novembro de 2014

E-mail: fernanda.machado@embrapa.br

Apoio financeiro: Conselho Nacional de Desenvolvimento Científico e Tecnológico (CNPq), Fundação de Amparo à Pesquisa do

Estado de Minas Gerais (FAPEMIG) RumenGases/Repensa Research Project (EMBRAPA). 
energia bruta e para a metabolizabilidade $\left(q_{m}\right)$. Foi observada interação $(P<0,05)$ entre híbrido de sorgo e estádio de maturação para eficiência de uso da energia metabolizável para mantença $\left(K_{m}\right)$, que variou entre 0,53 e 0,78. Não ocorreram diferenças $(p>0,10)$ entre tratamentos na produção diária de metano. A emissão de metano em gramas por $\mathrm{kg}$ de matéria seca digestível e por $\mathrm{kg}$ de fibra em detergente neutro digestível foi inferior no estádio pastoso comparado ao estádio farináceo.

Palavras-chave: energia líquida, gases de efeito estufa, respirometria, valor nutricional

\section{INTRODUCTION}

The importance of sorghum as a forage crop is growing in many regions of the world due to its high productivity and ability to utilize water efficiently even under drought conditions (Sanchez et al., 2002).

In vivo experiments with ruminants may be more adequate than in vitro examinations for the evaluation of the real nutritive value of silage varieties. The chemical composition of feed determines the potential energy available in the chemical bonds of the nutrients. However, after the feed is ingested, its chemical and physical properties such as composition, presence of antinutritional factors and overall particle size, can influence the animal's ability to use the potential energy present in the nutrients. Moreover, the characteristics of the animal also determine the efficiency of energy use.

To determine the efficiency of energy use, the energy losses which occur via feces, urine, methane and heat should be measured. In energy metabolism studies, heat produced by animals is measured as total heat production, which includes the heat used for maintenance and wasted as heat increment. Respiration calorimetry is the usual method used to determine methane and heat production in energy metabolism studies in farm animals in developed countries, while in tropical based developing countries this kind of assay is scarce due to the unavailability of facilities with respirometry chambers. The introduction of calorimetric studies in tropical conditions is important for conceptual advances in roughage evaluation, enabling for more accurate analysis of utilization, and optimizing livestock performance (Rodriguez et al., 2007).

Methane emissions from ruminant livestock have been measured in traditional studies of ruminal fermentation and energy balance, and lately as a greenhouse gas (Mwenya et al., 2004). Besides its contribution to global warming, methane represents a loss of energy for the animal, accounting for $2 \%$ to $12 \%$ of gross energy intake (Johnson and Johnson, 1995). There is a scarcity of published literature regarding the effects of tropical forages' maturity at harvest on energy balance and methane emissions by ruminants.

There is substantial genetic diversity among sorghum hybrids and stage of maturity of the grains at harvest, which should determine different nutritional values for silage production. The aims of this study were to examine the effects of sorghum genetics and stages of maturity at harvest on energy intake, energy partitioning, and efficiency of energy use and methane production by sheep.

\section{MATERIALS AND METHODS}

Three commercially available sorghum hybrids (BRS 610, BR 700 and BRS 655) were seeded in rows with 70-cm spacing on November, 9, 2006 at Embrapa Maize and Sorghum research farm, in Sete Lagoas, Minas Gerais, Brazil. In addition, $350 \mathrm{~kg} / \mathrm{ha}$ of $08-28-16$ (N-P-K) fertilizer were included at seeding. When sorghum plants had 5 leaves, $100 \mathrm{~kg}$ of urea were applied per hectare. Each sorghum hybrid was harvested at three cut ages, at different stages of maturity of the grains: milk, soft dough and floury. Sorghum was harvested at ground level using a precision chopharvester set to a theoretical cut length of $7.0 \mathrm{~mm}$. Climatic conditions (rainfall and temperature) between seeding and harvest of sorghum hybrids are shown in Figure 1.

Freshly harvested sorghum was ensiled in 200L metallic barrels, lined with plastic bags, sealed and stored for $400 \mathrm{~d}$ before the initiation of the trial. Chemical composition of silages is given in Table 1. 


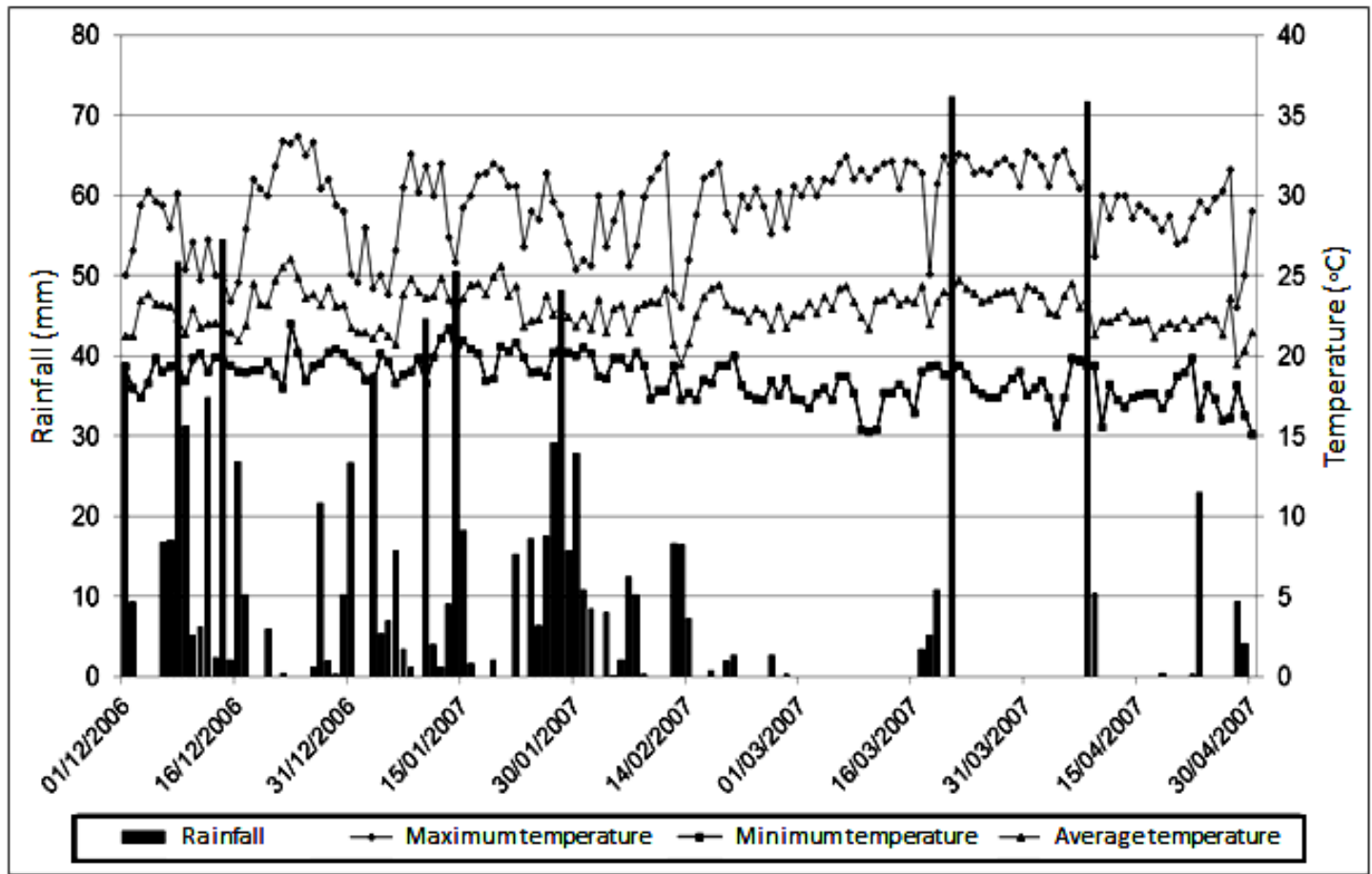

Figure 1. Rainfall (mm), average, maximum and minimum temperature $\left({ }^{\circ} \mathrm{C}\right)$ between December 2006 and April 2007 in Sete Lagoas (19.4658 S, 44.2469 $\mathrm{W})$, Minas Gerais, Brazil.

Table 1. Chemical composition (\% dry matter (DM) basis) of the silages of the sorghum hybrids BRS 610, BR 700 and BRS 655 in three maturation stages (milk, soft dough and floury)

\begin{tabular}{|c|c|c|c|c|c|c|c|}
\hline \multirow[b]{2}{*}{ Hybrids } & \multirow[b]{2}{*}{$\begin{array}{c}\text { DM } \\
\text { content, } \%\end{array}$} & \multicolumn{6}{|c|}{$\%$ in the DM } \\
\hline & & $\begin{array}{l}\text { Crude } \\
\text { protein }\end{array}$ & $\begin{array}{c}\text { Neutral } \\
\text { detergent } \\
\text { fiber }\end{array}$ & $\begin{array}{c}\text { Acid } \\
\text { detergent } \\
\text { fiber }\end{array}$ & Cellulose & Hemicellulose & Lignin \\
\hline & \multicolumn{7}{|c|}{ Milk } \\
\hline BRS 610 & 22.3 & 6.9 & 61.6 & 36.2 & 31.0 & 25.4 & 5.2 \\
\hline BR 700 & 29.5 & 6.7 & 60.3 & 33.4 & 27.4 & 26.9 & 6.0 \\
\hline \multirow[t]{2}{*}{ BRS 655} & 22.6 & 6,42 & 63.7 & 37.7 & 31.8 & 25.9 & 5.9 \\
\hline & \multicolumn{7}{|c|}{ Soft dough } \\
\hline BRS 610 & 23.9 & 6.7 & 59.5 & 35.3 & 29.4 & 24.3 & 5.9 \\
\hline BR 700 & 32.1 & 6.2 & 61.4 & 34.6 & 28.2 & 26.8 & 6.4 \\
\hline \multirow[t]{2}{*}{ BRS 655} & 25.0 & 6.1 & 63.9 & 35.3 & 29.9 & 28.6 & 5.4 \\
\hline & \multicolumn{7}{|c|}{ Floury } \\
\hline BRS 610 & 27.0 & 6.4 & 55.0 & 31.2 & 25.9 & 23.8 & 5.3 \\
\hline BR 700 & 38.1 & 6.1 & 63.9 & 35.0 & 29.2 & 29.0 & 5.8 \\
\hline BRS 655 & 25.1 & 6.8 & 61.4 & 33.5 & 27.2 & 27.9 & 6.3 \\
\hline
\end{tabular}

All animal procedures used in this study were approved by the Institutional Animal Care and Use Committee of the Universidade Federal de Minas Gerais (Belo Horizonte, Brazil). Forty five mature castrated wether sheep (average live weight of $47.5 \mathrm{~kg}$ ) were randomly assigned to treatments in a $3 \times 3$ factorial arrangement. The treatments were the silage sorghum hybrids BRS 610, BR 700 and BRS 655 harvested at three maturation stages of the grains: milk, soft dough and floury. Sheep were housed individually in metabolic cages and fed individually at $60-80 \mathrm{~g}$ $\mathrm{DM} / \mathrm{kg} \mathrm{BW}^{0.75}$ per day, twice daily at 06:00 and 17:30h. Mineral premix and clean water were 
available ad libitum. All the animals were weighed before and after the trial. Feed intake was recorded daily.

Diets were fed for a 28 day adaptation followed by a 5 day collection period. Representative samples $(10 \%$ of total amount) of feed offered and residue left were taken daily during collection period. On days 2-5 of the collection period, total daily feces and urine were collected and weighed from each animal. Urine was collected into buckets with $50 \mathrm{~mL}$ of $10 \%(\mathrm{v} / \mathrm{v})$ sulfuric acid. At the end of the collection period, residue of feeds, feces and urine were pooled by sheep and subsamples taken for analyses. Fecal samples were initially dried in a forced air oven at $55^{\circ} \mathrm{C}$ for $72 \mathrm{~h}$ while urine samples were stored at $-18^{\circ} \mathrm{C}$. Samples of feed, residue of feeds and feces were Wiley mill ground ( $1 \mathrm{~mm}$ screen) for subsequent analyses.

After the digestion study, oxygen consumption, carbon dioxide production, and methane emissions were monitored for $24 \mathrm{~h}$ on individual sheep one after the other, by an open-circuit respiration chamber for small ruminants. The selected animal was weighed before entering and after exiting the chamber. The animals were maintained on the prescribed nutritional regime. Weighed quantities of silage were given in the feed bin attached to the metabolic crate kept inside the chamber. Animals inside the chamber were provided with sufficient water. Fasting heat production was determined after withholding feed for $72 \mathrm{~h}$, but water made available throughout.

After placing the feed inside, the chamber was made airtight and the pump was started along with the ventilation system of the chamber for pulling and conditioning the air. Observations on gaseous exchange were recorded for $24 \mathrm{~h}$, after an adaptation period of two days in another similar respiration chamber. Recording the temperature, humidity, flow rate, atmospheric pressure, air sampling and gas analyses was done by Sable Systems International equipment. The samples of outgoing and incoming air were continuously analyzed at $5 \mathrm{~min}$ intervals. The chamber was opened after $24 \mathrm{~h}$. The residues of feeds, voided feces and urine excreted were collected and measured. Representative samples of feed offered, residue left, feces and urine were drawn and preserved for nitrogen and energy estimation.

The equipment and procedure utilized for the respiration study were described by Rodriguez et al. (2007). The chamber, located at the Universidade Federal de Minas Gerais, Brazil, was developed for small ruminants and built with transparent acrylic resin plates with external dimensions of $1.2 \mathrm{~m}$ (wide) $\times 2.0 \mathrm{~m}$ (height) $\times$ $2.1 \mathrm{~m}$ (length). The chamber was maintained at $21-25^{\circ} \mathrm{C}$ with relative humidity of ca. $65 \%$. Oxygen concentrations were determined by a paramagnetic oxygen analyzer (PA-1B oxygen analyzer; Sable Systems International, USA). Carbon dioxide and methane measurements were conducted by infra-red gas analyzers (CA-10A Carbon dioxide Analyzer; MA-1 Methane Analyzer, Sable Systems International, USA). The flow rate of the air pulled from the chamber was measured by a mass flow sensor (Flow-Kit500; Sable Systems International, USA).

Chemical analyses were performed on each sample in duplicate, and when the coefficient of variation $(\mathrm{CV})$ for the replicate analysis was more than $5 \%$, analysis was repeated. The dry matter (DM) and total nitrogen $(\mathrm{N})$ of feed (Table 1), residue, urine and fecal samples were determined by methods 967.03 and 984.13, respectively from the Official Methods of Analysis of Association of Official Analytical Chemists (Official..., 2000). Energy content in feed, residue, feces and urine were determined with an adiabatic bomb calorimeter (PARR 2081).

Intake of ME (MEI) was the difference between GE intake and energy losses in feces, urine, and $\mathrm{CH}_{4}$. Intake of $\mathrm{NE}$ (NEI) was the difference between MEI and heat increment. Heat energy was estimated based on the Brouwer (1965) equation for $\mathrm{O}_{2}$ consumption and $\mathrm{CO}_{2}$ and $\mathrm{CH}_{4}$ production on days of gas exchange measurement, as well as urinary $\mathrm{N}$ excretion. Energy lost as $\mathrm{CH}_{4}$ was estimated as total $\mathrm{CH}_{4}$ emitted in $\mathrm{g} / \mathrm{d} \times 13,334 \mathrm{kcal} / \mathrm{g}$ (Brouwer, 1965). Heat increment was obtained by the difference between the heat production observed for the animal fed with silage and fasting heat production. The metabolizability $\left(\mathrm{q}_{\mathrm{m}}\right)$ and the efficiency of ME used for maintenance $(\mathrm{km})$ were estimated from the equation of AFRC (1993). 
The experimental design utilized was completely randomized in a $3 \times 3$ factorial arrangement. The experimental unit was each individual animal. Analysis of variance (ANOVA) was used to analyze data using the general linear model procedure (GLM, SAS, 2013), as per the following statistical model:

$$
\mathrm{Yij}=\mu+\mathrm{Hi}+\mathrm{MSj}+\left(\mathrm{H}^{*} \mathrm{MS}\right) \mathrm{ij}+e \mathrm{ij}
$$

where $\mu$ is the mean, $H$ is the effect of sorghum hybrid, MS is the effect of maturation stage, $\mathrm{H}^{*} \mathrm{MS}$ is the interaction between hybrid and maturation stage and $e$ is the random error.
Main effects and interactions of hybrid and maturation stage were evaluated. Treatment means were differentiated using StudentNewman-Keuls (SNK) test (SAS, 2013). Pearson's correlation coefficient (r) was used to measure the association between the parameters. Significance was declared when $\mathrm{P} \leq 0.05$ and a trend reported when $0.05<\mathrm{P}<0.10$.

\section{RESULTS AND DISCUSSION}

The intake of dry matter and digestible dry matter were not affected by maturation stage of the silages (Table 2).

Table 2. Daily intake of dry matter and energy by sheep fed silages of the sorghum hybrids BRS 610, BR 700 and BRS 655 in three maturation stages (MS: milk, soft dough and floury)

\begin{tabular}{|c|c|c|c|c|c|c|c|}
\hline Hybrids & MS & DMI & DDMI & GEI & DEI & MEI & NEI \\
\hline \multirow[t]{3}{*}{ BRS 610} & M & 60.0 & 26.9 & 225.6 & 113.9 & 99.0 & 68.8 \\
\hline & SD & 56.7 & 32.2 & 238.6 & 138.7 & 125.5 & 96.2 \\
\hline & $\mathrm{F}$ & 54.5 & 30.4 & 248.3 & 128.3 & 114.8 & 78.1 \\
\hline \multirow[t]{3}{*}{ BR 700} & M & 52.5 & 29.3 & 218.6 & 120.9 & 109.1 & 74.4 \\
\hline & SD & 56.5 & 27.4 & 233.4 & 111.6 & 100.2 & 72.7 \\
\hline & $\mathrm{F}$ & 55.1 & 28.4 & 233.6 & 121.9 & 106.2 & 76.1 \\
\hline \multirow[t]{3}{*}{ BRS 655} & M & 46.2 & 24.6 & 192.9 & 104.2 & 90.1 & 55.5 \\
\hline & SD & 45.9 & 23.9 & 193.5 & 100.1 & 89.7 & 70.4 \\
\hline & F & 51.2 & 24.7 & 213.7 & 104.3 & 89.4 & 47.7 \\
\hline SEM & & 2.62 & 1.79 & 11.13 & 7.42 & 7.06 & 6.56 \\
\hline \multicolumn{8}{|l|}{ Main effects } \\
\hline \multicolumn{8}{|l|}{ Hybrids } \\
\hline BRS 610 & & $57.1 \mathrm{~A}$ & $29.8 \mathrm{~A}$ & $237.5 \mathrm{~A}$ & $127.0 \mathrm{~A}$ & $113.1 \mathrm{~A}$ & $81.2 \mathrm{~A}$ \\
\hline BR 700 & & $54.7 \mathrm{AB}$ & $28.4 \mathrm{~A}$ & $228.5 \mathrm{~A}$ & $118.1 \mathrm{~A}$ & $105.2 \mathrm{~A}$ & $74.4 \mathrm{~A}$ \\
\hline BRS 655 & & $47.8 \mathrm{~B}$ & $24.4 \mathrm{~B}$ & $200.0 \mathrm{~B}$ & $102.9 \mathrm{~B}$ & 89.8 B & $57.9 \mathrm{~B}$ \\
\hline \multicolumn{8}{|l|}{ Maturation stage } \\
\hline Milk & & 52.9 & 26.9 & 212.4 & 113.0 & 99.4 & $66.3 \mathrm{~b}$ \\
\hline Soft dough & & 53.1 & 27.8 & 221.9 & 116.8 & 105.1 & $79.8 \mathrm{a}$ \\
\hline \multirow[t]{2}{*}{ Floury } & & 53.6 & 27.9 & 231.8 & 118.2 & 103.5 & $67.3 \mathrm{~b}$ \\
\hline & & \multicolumn{6}{|c|}{ P-Values } \\
\hline Hybrids $(\mathrm{H})$ & & $<0.01$ & $<0.01$ & $<0.01$ & $<0.01$ & $<0.01$ & $<0.01$ \\
\hline $\begin{array}{l}\text { Maturation stage } \\
\text { (MS) }\end{array}$ & & 0.14 & 0.77 & 0.12 & 0.68 & 0.60 & 0.03 \\
\hline $\mathrm{H} \times \mathrm{MS}$ & & 0.77 & 0.33 & 0.92 & 0.21 & 0.17 & 0.14 \\
\hline
\end{tabular}

MS: Maturation stage; M: Milk; SD: Soft dough; F: Floury; DMI: Dry matter intake; DDMI: Digestible dry matter intake; GEI: Gross energy intake; DEI: Digestible energy intake; MEI: Metabolizable energy intake; NEI: Net energy intake; SEM: Standard error of mean. Means of the hybrids followed by the same capital letters in columns and means of the maturations stages followed by the same lowercase letters in columns do not differ significantly by the SNK test $(\mathrm{P}<0.05)$.

Sheep fed BRS 610 silage had higher $(\mathrm{P}<0.01)$ dry matter intake compared to sheep fed BRS 655 silage. Digestible dry matter intake was lower $(\mathrm{P}<0.01)$ in sheep fed BRS 655 compared to those fed BRS 610 and BR 700 silages. The stage of maturity at harvest had no effects on intake of gross energy, digestible energy or metabolizable energy. Net energy intake was affected by maturation stage, with the soft dough stage having higher value than milk and floury stages. Sheep fed BRS 655 silage consumed less $(\mathrm{P}<0.01)$ gross, digestible, metabolizable and net energy compared to others hybrids. BRS 610 and BR 700 silages had similar values to these parameters. 
The lower gross energy intake by the animals fed the silage of sorghum BRS 655 reflects the lower intake of dry matter for this hybrid, which is in agreement with the high correlation between these parameters $(\mathrm{r}$ DMI $\times$ GEI $=0.997, \mathrm{P}<0.01)$. Decreasing values were observed for the correlations between dry matter intake and digestible energy intake $(\mathrm{r}$ DMI $\times$ DEI $=0.689$, $\mathrm{P}<0.01$ ), metabolizable energy intake $\mathrm{r}_{\mathrm{DMI} \times \mathrm{MEI}}=$ $0.655, \mathrm{P}<0.01)$ and net energy intake $\left(\mathrm{r}_{\mathrm{DMI}} \times \mathrm{NEI}=\right.$ $0.492, \mathrm{P}<0.01)$.

No differences $(\mathrm{P}>0.10)$ among treatments occurred in the energy loss via feces (Table 3 ). There was an interaction $(\mathrm{P}<0.01)$ between sorghum hybrid and maturation stage for the urine energy excretion $\left(\mathrm{kcal} / \mathrm{kg}^{0.75}\right.$ ) (Table 3 ). For the BRS 610 hybrid, while soft dough and floury stages had similar energy loss via urine, the silage harvested at milk stage had the highest value. For the BR 700 hybrid, there were no differences $(\mathrm{P}>0.10)$ among maturation stages. For the BRS 655 hybrid, while the soft dough stage was similar to the other stages, the floury stage was higher than the milk stage. Comparing the hybrids at the milk stage, while the BR 700 and BRS 655 silages were similar, the BRS 610 had the highest value. At the soft dough stage there were not differences among the hybrids. At the floury stage, while the BRS 610 and BR 700 were similar, the BRS 655 had the highest value of urine energy excretion $\left(\mathrm{kcal} / \mathrm{kg}^{0.75}\right)$. The urine energy loss, as a percentage of gross energy intake (\% GE intake), was not affected by maturation stage. While the hybrid BRS 610 was similar to the other hybrids, the BRS 655 had a higher value than BR 700 .

Energy as methane was not affect by the treatments (Table 3). Methane emissions as a proportion of GE intake were lower than those reported by McGeough et al. (2010) for beef cattle offered maize silage.

There was an interaction $(\mathrm{P}<0.01)$ between sorghum hybrid and maturation stage for the heat increment $\left(\mathrm{kcal} / \mathrm{kg}^{0.75}\right)$ (Table 3). For the hybrids BRS 610 and BR 700, there were no differences ( $\mathrm{P}>0.10)$ among maturation stages. For BRS 655, while milk and floury stages were similar, soft dough stage had the lowest value. Comparing the hybrids at the milk stage, there were no differences among the hybrids. At the soft dough stage, the hybrid BRS 655 had the lowest value, while the hybrids BRS 610 and BR 700 were similar. At the floury stage, the silage of the hybrid BRS 610 was similar to the others, while the BRS 655 was higher than the BR 700. An interaction $(\mathrm{P}<0.01)$ between sorghum hybrid and maturation stage was observed for the heat increment, as a percent of gross energy intake (\% GE intake) (Table 3). For the hybrid BRS 610, the maturation stages were similar. For the BR 700, the stages soft dough and floury were similar, while the milk stage had the highest heat increment. For the BRS 655, the milk and floury stages were similar, while the lowest value was observed for the soft dough stage. Comparing the three hybrids at the milk stage, the silage of BR 700 was similar to other materials, while BRS 655 had a higher heat increment than BRS 610 . At the soft dough stage there were no differences among the hybrids. At the floury stage, BRS 610 and BR 700 were similar, while BRS 655 had the highest heat increment value.

The heat increment corresponds to the increase of heat due to intake of feed. Therefore, the magnitude of heat increment is influenced by the quantity, quality and balance of dietary components. As dry matter intake increases, the heat increment increases, since the digestion and transport of digesta over the digestive tract requires energy. The heat increment also depends on the dietary composition. For concentrates, the $\mathrm{HI}$ is $15 \%$ to $25 \%$ of the metabolizable energy, while for forages, the range is between $35 \%$ and $60 \%$ of ME (Johnson et al., 2003). In this trial, the $\mathrm{HI}$ ranged from $23.7 \%$ to $31.8 \%$ of $\mathrm{ME}$ for the hybrid BRS 610 ; from $28.1 \%$ to $31.7 \%$ of ME for BR 700 and from $22.2 \%$ to $46.8 \%$ of ME for the hybrid BRS 655. The highest value of HI for BRS 655 harvested in the soft dough stage is not related to the intake of silage, since the DMI for this treatment did not differ from other genotypes $(\mathrm{P}>0.10)$. Thus, low correlation between dry matter intake and heat increment $(r$ DMI $\times \mathrm{HI}=0.363, \mathrm{P}<0.01)$ indicates that other factors may have influenced the loss of energy as heat. Furthermore, the differences between the levels of consumption of the treatment may not have been sufficient to cause changes in the HI, since all silages showed DMI below 60 grams perkg $^{0.75}$, i.e., within maintenance level (60-80 $\left.\mathrm{g} / \mathrm{kg}^{0,75}\right)$. 
Table 3. Energy losses by sheep fed silages of the sorghum hybrids BRS 610, BR 700 and BRS 655 in three maturation stages (MS: milk, soft dough and floury)

\begin{tabular}{|c|c|c|c|c|c|c|c|c|c|}
\hline \multirow[b]{2}{*}{ Hybrids } & \multirow[b]{2}{*}{ MS } & \multicolumn{2}{|c|}{ Fecal energy } & \multicolumn{2}{|c|}{ Urinary energy } & \multicolumn{2}{|c|}{ Methane energy } & \multicolumn{2}{|c|}{ Heat increment } \\
\hline & & $\mathrm{kcal} / \mathrm{kg}^{0.75}$ & $\%$ GEI & $\mathrm{kcal} / \mathrm{kg}^{0.75}$ & $\begin{array}{c}\% \\
\text { GEI }\end{array}$ & $\mathrm{kcal} / \mathrm{kg}^{0.75}$ & $\begin{array}{c}\% \\
\text { GEI }\end{array}$ & $\mathrm{kcal} / \mathrm{kg}^{0.75}$ & $\%$ GEI \\
\hline \multirow[t]{3}{*}{ BRS 610} & M & 111.6 & 49.2 & $4.4 \mathrm{aA}$ & 1.98 & 10.6 & 4.6 & $30.2 \mathrm{aA}$ & $13.5 \mathrm{aB}$ \\
\hline & SD & 99.9 & 42.0 & $2.9 \mathrm{bA}$ & 1.21 & 10.4 & 4.3 & $29.3 \mathrm{aA}$ & $12.3 \mathrm{aA}$ \\
\hline & $\mathrm{F}$ & 120.0 & 48.5 & $2.4 \mathrm{bB}$ & 0.95 & 11.2 & 4.5 & $36.7 \mathrm{aAB}$ & $14.7 \mathrm{aB}$ \\
\hline \multirow[t]{3}{*}{ BR 700} & M & 97.7 & 44.2 & $2.4 \mathrm{aB}$ & 1.12 & 9.4 & 4.2 & $34.7 \mathrm{aA}$ & $\begin{array}{l}15.9 \\
\text { aAB }\end{array}$ \\
\hline & $\mathrm{SD}$ & 121.8 & 52.0 & $2.6 \mathrm{aA}$ & 1.1 & 8.8 & 3.8 & $27.5 \mathrm{aA}$ & $11.7 \mathrm{bA}$ \\
\hline & $\mathrm{F}$ & 111.6 & 47.9 & $2.74 \mathrm{aB}$ & 1.17 & 13.0 & 5.5 & $30.1 \mathrm{aB}$ & $12.9 \mathrm{bB}$ \\
\hline \multirow[t]{3}{*}{ BRS 655} & M & 88.7 & 45.7 & $2.8 \mathrm{bB}$ & 1.48 & 11.3 & 5.8 & $34.6 \mathrm{aA}$ & $18.0 \mathrm{aA}$ \\
\hline & $\mathrm{SD}$ & 93.4 & 48.3 & $3.1 \mathrm{abA}$ & 1.72 & 7.3 & 3.9 & $19.3 \mathrm{bB}$ & $10.1 \mathrm{bA}$ \\
\hline & $\mathrm{F}$ & 109.3 & 50.8 & $4.5 \mathrm{aA}$ & 2.15 & 10.4 & 5.0 & $41.7 \mathrm{aA}$ & $19.5 \mathrm{aA}$ \\
\hline SEM & & 8.76 & 2.86 & 0.48 & 0.280 & 1.32 & 0.54 & 2.73 & 1.01 \\
\hline \multicolumn{10}{|l|}{$\begin{array}{l}\text { Main effects } \\
\text { Hybrids }\end{array}$} \\
\hline BRS 610 & & 110.5 & 46.6 & 3.2 & $\begin{array}{l}1.4 \\
\mathrm{AB}\end{array}$ & 10.7 & 4.5 & 32.1 & 13.5 \\
\hline BR 700 & & 110.4 & 48.1 & 2.6 & $1.1 \mathrm{~B}$ & 10.4 & 4.5 & 30.8 & 13.5 \\
\hline BRS 655 & & 97.2 & 48.3 & 3.5 & $1.8 \mathrm{~A}$ & 9.7 & 4.9 & 31.9 & 15.9 \\
\hline \multicolumn{10}{|l|}{$\begin{array}{l}\text { Maturation } \\
\text { stage }\end{array}$} \\
\hline Milk & & 99.4 & 46.4 & 3.2 & 1.5 & 10.4 & 4.9 & 33.2 & 15.8 \\
\hline Soft dough & & 105.1 & 47.5 & 2.9 & 1.3 & 8.8 & 4.0 & 25.4 & 11.4 \\
\hline \multirow[t]{2}{*}{ Floury } & & 113.7 & 49.1 & 3.2 & 1.4 & 11.5 & 5.0 & 36.2 & 15.7 \\
\hline & & \multicolumn{8}{|c|}{$\mathrm{P}$-values } \\
\hline Hybrids $(\mathrm{H})$ & & 0.11 & 0.73 & 0.08 & 0.02 & 0.61 & 0.59 & 0.82 & 0.01 \\
\hline $\begin{array}{l}\text { Maturation } \\
\text { stage (MS) }\end{array}$ & & 0.15 & 0.51 & 0.62 & 0.71 & 0.05 & 0.06 & $<0.01$ & $<0.01$ \\
\hline $\mathrm{H} \times \mathrm{MS}$ & & 0.27 & 0.12 & 0.01 & 0.06 & 0.34 & 0.21 & $<0.01$ & 0.01 \\
\hline
\end{tabular}

MS: Maturation stage; M: Milk; SD: Soft dough; F: Floury; SEM: Standard error of mean. Means of the hybrids followed by the same capital letters in columns and means of the maturation stages followed by the same lowercase letters in columns do not differ significantly by the SNK test $(\mathrm{P}<0.05)$.

The fecal output represented the main source of energy loss, as a percentage of gross energy intake $(48 \%$ to $52 \%)$, followed by the heat increment $(10 \%$ to $19 \%)$, methane emissions ( $4 \%$ to $6 \%$ ) and urine (1\% to $2 \%)$. Therefore, the development of nutritional strategies and technologies to improve the digestibility and decrease the heat increment is very important. This will maximize the energy flow in the animal toward the production of meat and milk.

There were no differences among the treatments for the apparent digestibility of gross energy and metabolizability (Table 4).

The apparent digestible gross energy (ADGE) can be considered quite similar to total digestible nutrients (TDN) and possibly even more accurate, since it is the sum of the combustion heat of the true digestible nutrients (protein, lipids and carbohydrates). Thus, the value of ADGE suffers lower interference of non-lipid components of the ether extract (waxes, pigments, terpenes), as well of the errors associated with the various laboratory chemical analyzes needed to estimate the TDN. Black et al. (1980) reported values of TDN for sorghum silage between $64.9 \%$ at early bloom stage and $50.5 \%$ at dough stage, which is similar to the present study. In both experiments, the crude protein levels were below maintenance levels, which may have decreased digestibility.

The metabolizability $\left(\mathrm{q}_{\mathrm{m}}\right)$ ranged between 0.42 and 0.52 , with no statistical differences among treatments $(\mathrm{P}>0.10)$. 
Energy partitioning...

Table 4. Energy efficiency by sheep fed silages of the sorghum hybrids BRS 610, BR 700 and BRS 655 in three maturation stages (milk, soft dough and floury)

\begin{tabular}{llllll}
\hline Hybrids & MS & ADGE & $\mathrm{q}_{\mathrm{m}}$ & $\mathrm{km}$ & $\mathrm{NE}(\% \mathrm{GE})$ \\
\hline BRS 610 & $\mathrm{M}$ & 50.8 & 0.44 & $0.69 \mathrm{Aa}$ & 30.7 \\
& $\mathrm{SD}$ & 58.0 & 0.52 & $0.76 \mathrm{Aa}$ & 40.1 \\
& $\mathrm{~F}$ & 51.5 & 0.46 & $0.68 \mathrm{Aa}$ & 31.5 \\
BR 700 & $\mathrm{M}$ & 55.8 & 0.5 & $0.68 \mathrm{Aa}$ & 34.5 \\
& $\mathrm{SD}$ & 48.0 & 0.43 & $0.72 \mathrm{Aa}$ & 31.4 \\
& $\mathrm{~F}$ & 52.1 & 0.45 & $0.71 \mathrm{Aa}$ & 32.5 \\
BRS 655 & $\mathrm{M}$ & 54.3 & 0.47 & $0.61 \mathrm{Ab}$ & 29.0 \\
& $\mathrm{SD}$ & 51.7 & 0.46 & $0.78 \mathrm{Aa}$ & 36.0 \\
SEM & $\mathrm{F}$ & 49.2 & 0.42 & $0.53 \mathrm{Bc}$ & 22.6 \\
Main effects & & 2.86 & 0.030 & 0.03 & 2.7 \\
Hybrids & & & & & \\
BRS 610 & & 53.4 & 0.47 & 0.71 & 34.1 \\
BR 700 & & 52.0 & 0.46 & 0.7 & 32.8 \\
BRS 655 & & 51.7 & 0.45 & 0.64 & 29.2 \\
Maturation stage & & & & & \\
Milk & 53.6 & 0.47 & 0.66 & $31.4 \mathrm{ab}$ \\
Soft dough & 52.6 & 0.47 & 0.75 & $35.8 \mathrm{a}$ \\
Floury & & 50.9 & 0.44 & 0.64 & $28.8 \mathrm{~b}$ \\
& & & & \\
Hybrids (H) & & 0.73 & 0.52 & $<0.01$ & 0.09 \\
Maturation stage (MS) & & 0.51 & 0.36 & $<0.01$ & 0.01 \\
H × MS & 0.12 & 0.11 & $<0.01$ & 0.06 \\
\hline
\end{tabular}

MS: Maturation stage; M: Milk; SD: Soft dough; F: Floury; ADGE: Apparent digestible gross energy $=100$ - (GE feces/GE feed); qm: Metabolizability ([ME]/[GE]); km: Efficiency of ME utilization for maintenance; $\mathrm{NE}$ (\%GE): Net energy to gross energy ratio (\%); SEM: Standard error of mean. Means of the hybrids followed by the same capital letters in columns and means of the maturation stages followed by the same lowercase letters in columns do not differ significantly by the SNK test $(\mathrm{P}<0.05)$.

Since the metabolizability represents the relation between metabolizable energy (ME) and gross energy (GE), it is expected that energy losses as feces, urine and methane determine its value. Given the large share of fecal output in the total energy losses by the animal, there is a high correlation between the apparent digestibility of gross energy and metabolizability $\left(\mathrm{r}_{\mathrm{qm}} \times\right.$ ADGE $=$ $0.97, \mathrm{P}<0.01)$. In this experiment, the low values of $\mathrm{q}_{\mathrm{m}}$ and ADGE may be associated with grain in the feces.

An interaction $(\mathrm{P}<0.01)$ between sorghum hybrid and maturation stage was observed for the efficiency of ME utilization for maintenance (Table 4). For the hybrids BRS 610 and BR 700, there were no differences ( $P>0.10)$ among maturation stages. For the hybrid BRS 655, the silage harvested at the soft dough stage had the highest $\mathrm{Km}$, whereas the floury stage had lower
$\mathrm{Km}$ than milk stage. Comparing the hybrids at the same maturation stage, no differences were observed among the hybrids at the milk and soft dough stage. At the floury stage, the silage of BRS 655 sorghum had the lowest $\mathrm{Km}$. Literature data indicate that the efficiency of energy used for maintenance is relatively constant regardless of food composition. Armstrong and Blaxter (1957) demonstrated that the heat increment for mixtures of volatile fatty acids (VFA) was influenced by the ratio of acetate: propionate in sheep fattening, but had little effect on sheep fed at maintenance level. According to Fox et al. (2004), $\mathrm{km}$ values vary from 0.576 , for diets with $\mathrm{ME}$ of $2.0 \mathrm{Mcal} / \mathrm{kg}$ (typical for temperate grasses in late flowering stage), to 0.651 , for diets with $\mathrm{ME}$ of $2.6 \mathrm{Mcal} / \mathrm{kg}$ (typical for corn silage), and up to 0.686 , for diets with ME of $3.2 \mathrm{Mcal} / \mathrm{kg}$ (corn kernels). 
Net energy to gross energy ratio (\%) was affected by maturation stage (Table 4 ). The milk stage was similar to the other maturation stages, whereas the silage harvested at the soft dough stage had higher NE/GE ratio than that harvested at the floury stage.
A tendency $(\mathrm{P}=0.06)$ for $\mathrm{BRS} 655$ silage harvested at the floury stage to have lower $\mathrm{NE} / \mathrm{GE}$ ratio than the other silages at the same maturation stage was observed.

Table 5. Methane production by sheep fed silages of the sorghum hybrids BRS 610, BR 700 and BRS 655 in three maturation stages (milk, soft dough and floury)

\begin{tabular}{|c|c|c|c|c|c|c|}
\hline Hybrids & MS & $\begin{array}{l}\mathrm{CH}_{4} \\
(\mathrm{~L} / \mathrm{d})\end{array}$ & $\begin{array}{c}\mathrm{CH}_{4} \\
\text { (L/UTM) }\end{array}$ & $\begin{array}{c}\mathrm{CH}_{4} \\
(\mathrm{~g} / \mathrm{kg} \mathrm{DM})\end{array}$ & $\begin{array}{c}\mathrm{CH}_{4} \\
(\mathrm{~g} / \mathrm{kg} \mathrm{DDM})\end{array}$ & $\begin{array}{c}\mathrm{CH}_{4} \\
(\mathrm{~g} / \mathrm{kg} \mathrm{NDFD})\end{array}$ \\
\hline \multirow[t]{3}{*}{ BRS 610} & $\mathrm{M}$ & 20.9 & 1.1 & 14.3 & 29.9 & 59.4 \\
\hline & SD & 19.2 & 1.1 & 13.6 & 24.1 & 46.7 \\
\hline & $\mathrm{F}$ & 22.4 & 1.2 & 13.8 & 27.0 & 73.0 \\
\hline \multirow[t]{3}{*}{ BR 700} & M & 18.0 & 1.0 & 13.2 & 23.9 & 49.4 \\
\hline & $\mathrm{SD}$ & 16.7 & 0.9 & 11.7 & 24.2 & 51.6 \\
\hline & $\mathrm{F}$ & 24.5 & 1.4 & 17.6 & 34.4 & 67.5 \\
\hline \multirow[t]{3}{*}{ BRS 655} & M & 22.3 & 1.2 & 18.2 & 33.8 & 62.0 \\
\hline & $\mathrm{SD}$ & 13.6 & 0.8 & 12.2 & 24.3 & 46.1 \\
\hline & $\mathrm{F}$ & 20.3 & 1.1 & 15.5 & 32.1 & 64.9 \\
\hline SEM & & 3.36 & 0.14 & 1.70 & 3.43 & 7.59 \\
\hline \multicolumn{7}{|l|}{ Main effects } \\
\hline \multicolumn{7}{|l|}{ Hybrids } \\
\hline BRS 610 & & 20.8 & 1.1 & 13.9 & 27.0 & 59.7 \\
\hline BR 700 & & 19.7 & 1.1 & 14.2 & 27.5 & 56.2 \\
\hline BRS 655 & & 18.8 & 1.0 & 15.3 & 30.0 & 57.7 \\
\hline \multicolumn{7}{|l|}{ Maturation stage } \\
\hline Milk & & 20.4 & 1.1 & 15.3 & $29.2 \mathrm{AB}$ & $56.9 \mathrm{AB}$ \\
\hline Soft dough & & 16.5 & 0.9 & 12.5 & $24.2 \mathrm{~B}$ & $48.1 \mathrm{~B}$ \\
\hline \multirow[t]{2}{*}{ Floury } & & 22.4 & 1.2 & 15.6 & $31.2 \mathrm{~A}$ & $68.5 \mathrm{~A}$ \\
\hline & & & & P-values & & \\
\hline Hybrids $(\mathrm{H})$ & & 0.75 & 0.61 & 0.57 & 0.51 & 0.85 \\
\hline Maturation stage (MS) & & 0.10 & 0.05 & 0.06 & 0.05 & 0.01 \\
\hline $\mathrm{H} \times \mathrm{MS}$ & & 0.67 & 0.34 & 0.17 & 0.28 & 0.72 \\
\hline
\end{tabular}

MS: Maturation stage; M: Milk; SD: Soft dough; F: Floury; UTM: Unit of metabolic weight $\left(\mathrm{kg}^{0.75}\right)$; DM: Dry matter; DDM: Digestible dry mater; NDFD: Digestible neutral detergent fiber; SEM: Standard error of mean. Means of the hybrids followed by the same capital letters in columns and means of the maturation stages followed by the same lowercase letters in columns do not differ significantly by the SNK test $(\mathrm{P}<0.05)$.

Methane emissions, in liters per day and liters per kilogram of metabolic weight, were not affected by sorghum maturity at harvest (Table 5 ), and this agrees with the results for maize silage of Nishida et al. (2007) and McGeough et al. (2010). When methane output was expressed relative to DMI, there was no effect of sorghum silage maturity in the present study, while McGeough et al. (2010) reported a tendency toward a linear decline in response to advancing maize maturity at harvest. These authors explained that the increase in starch concentration and simultaneous decline in fiber concentration have been reported to shift rumen fermentation toward propionic acid formation (Sutton et al., 2000), resulting in a decline in the methanogenesis. However, this was not the case in the present experiment, where intake of digestible dry matter or digestibility of energy showed no change with the advance of maturity. On the other hand, methane emission, expressed as $\mathrm{g} / \mathrm{kg}$ per digestible dry matter intake, differed among the maturation stages. The same was observed for methane emission as $\mathrm{g} / \mathrm{kg}$ per digestible NDF intake. Milk stage was similar to other maturation stages, while the soft dough stage had lower emission than the floury stage.

Several studies in the literature attributed antimetanogenic activity to tannis, especially to the group of condensed tannins (Sarvan, 2000, Woodward et al., 2001; Tiemann et al., 2008). The action of condensed tannins in methanogenesis can be attributed to an indirect 
effect by reducing the production of $\mathrm{H} 2$, as a consequence of the reduction in fiber digestibility, and direct inhibitory effect on the methanogenic population (Woodward et al., 2001).

No differences were observed among the methane output by sheep that received silage of the hybrid BRS 610 (without tannin) and those sheep fed silages of the hybrids BRS 700 and BR 655 (with tannin). Likewise, Oliveira et al. (2006), evaluating the effect of diets containing sorghum silage with low and high tannin content, provided for beef cattle, found no effect of these compounds on methanogenesis $\left(\mathrm{SF}_{6}\right.$ tracer technique).

Hybrid differences examined in the present study indicate that plant genetics affect dry matter intake and, consequently, energy intake. Both genetics and sorghum maturity at harvest have an effect on intake of net energy. This conclusion would indicate that there is substantial genetic diversity within sorghum species, determining different nutritional values. Sorghum hybrids need to be evaluated for advances in breeding programs, in order to guide technicians in choosing the hybrid suitable for silage production and optimum stage of maturity of the grains at harvest. The lack of differences in total daily methane output indicates that sorghum genetics and maturity at harvest should not be an opportunity to reduce the contribution of agriculture to total greenhouse gas emissions.

\section{REFERENCES}

AFRC. Energy and protein requirements of ruminants. Wallingford, UK: Cab international, 1993. $159 \mathrm{p}$.

ARMSTRONG，D.G.; BLAXTER，K.L. The heat increment of steam-volatile fatty acids in fasting sheep. Brit. J. Nutr., v.11, p.247-272., 1957.

BLACK，J.R.; ELY，L.O.; MCCULLOUGH, M.E.; SUDWEEKS, E.M. Effects of Stage of Maturity and Silage Additives upon the Yield of Gross and digestible Energy in Sorghum Silage. J. Animal Sci., v.50, p.617-624, 1980.
BROWER, E. Report of sub-committee on constants and factors. Symposium of Energy Metabolism held at European Association for Animal Production, 1965. London: EAAP Academic, 1965. p.441-443.

FOX, D.G.; TEDESCHI, L.O.; TYLUTKI, T.P. et al. The Cornell Net Carbohydrate and Protein System model for evaluating herd nutrition and nutrient excretion. Anim. Feed Sci. Tech., v.112, p.29-78, 2004.

JOHNSON, D.E.; FERRELL, C.L.; JENKINS, T.G. The history of energetic efficiency research: Where have we been and where are we? $J$. Animal Sci., v.81, p.27-38, 2003.

JOHNSON, K.A.; JOHNSON, D.E. Methane emissions from cattle. J. Anim. Sci., v.73, p.2483-2492, 1995.

MWENYA, B.; SANTOSO, B.; SAR, C. et al. Effects of including $\beta 1-4$ galactooligosaccharides, lactic acid bacteria or yeast culture on methanogenesis as well as energy and nitrogen metabolism in sheep. Animal Feed Sci. Tech., v.115, p.313-326, 2004.

McGEOUGH, E.J.; KIELY, P.O.; FOLEY, P.A. et al. Methane emissions, feed intake, and performance of finishing beef cattle offered maize silages harvested at 4 different stages of maturity. J. Anim. Sci., v.88, p.1479-191, 2010.

NISHIDA, T.; ERUDEN, B.; HOSODA, K. et al. Digestibility, methane production and chewing activity of steers fed whole-crop round bale corn silage preserved at three maturities. Anim. Feed Sci. Tech., v.135, p.42-51, 2007.

OFFICIAL methods of analysis of AOAC international. 17.ed. Gaithersburg: AOAC International, 2000. 2200p.

OLIVEIRA, S.G.; BERCHIELLI, T.T.; PEDREIRA, M.S. et al. Effect of tannin levels in sorghum silage and concentrate supplementation on apparent digestibility and methane emission in beef cattle. Anim. Feed Sci. Tech., v.135, p.236-248, 2007.

RODRIGUEZ, N.M.; CAMPOS, W.E.; LACHICA, M.L. et al. A calorimetry system for metabolism trials. Arq. Bras. Med. Vet. Zoot., v.59, p.495500, 2007. 
SANCHEZ, A.C.; SUBUDHI, P.K.; ROSENOW, D.T.; NGUYEN, H.T. Mapping QTLs associated with drought resistance in sorghum (Sorghum bicolor L. Moench). Plant. Mol. Biol., v.48, p.713-726, 2002.

SARVAN T. S. 2000. Effect of bromochloromethane on methanogenesis, nutrient utilization and growth rate of lambs. MVSc Thesis, Indian Veterinary Research Institute, Izatnagar, India.

STATISTICAL Analisys Sistem - SAS. 2013. SAS OnlineDoc ${ }^{\circledR}$ 9.1.3. in SAS Inc., Cary, NC, USA.

SUTTON, J. D., S. B. CAMMELL, R. H. PHIPPS, D. E. BEEVER, AND D. J. HUMPHRIES. The effect of crop maturity on the nutritional value of maize silage for lactating dairy cows. 2. Ruminal and post-ruminal digestion. Anim. Sci. v.71, p.391400, 2000.
TIEMANN, T.T.; LASCANO, C.E.; WETTSTEIN, H.R. et al. Effect of the tropical tannin-rich shrub legumes Calliandra calothyrsus and Flemingia macrophylla on methane emission and nitrogen and energy balance in growing lambs. Animal, v.2, p.790-799, 2008.

WOODWARD, S.L.; WAGHORN， G.C.; LASSEY, K.R.; ULYATT, M.J. Early indications that feeding Lotus will reduce methane emissions from ruminants. Proceedings of New Zealand Society of Animal Production, v.61, p.23-26, 2001. 